\title{
Distribution and conservation status of Hylorchilus wrens (Troglodytidae) in Mexico
}

\author{
HECTOR GOMEZ DE SILVA
}

\section{Summary}

The two species of Hylorchilus wrens are endemic to Mexico and were considered "Vulnerable" by Collar et al. (1994). They are restricted to humid tropical forest growing over karstic terrain, but large areas of apparently suitable habitat exist where they have not yet been recorded. I explored areas of potentially suitable habitat as well as a few localities where they were already known to occur in order to gather new data for a re-evaluation of the conservation status of these species. My records, together with six localities where these species have been reported by others in the past few years, add 15 localities to the 12 listed by Collar et al. (1992). Based on this and other new information, I recommend "Endangered" status for Nava's Wren, $H$. navai, based on criterion B of Mace-Lande (extent of occurence $<5000 \mathrm{~km}^{2}$ ) and on the strongly fragmented state of its habitat. I would retain "Vulnerable" status for Sumichrast's Wren, H. sumichrasti, owing to its slightly larger range which is still relatively unfragmented and its apparently larger population density.

Las dos especies de Hylorchilus son endémicas a Mexico y se consideran "Vulnerables" de acuerdo con Collar et al. (1994). Están restringidas a bosque tropical húmedo en terreno kárstico, pero existen regiones extensas de hábitat aparentemente adecuado donde aún no se les ha registrado. Exploré regiones de hábitat potencial además de algunas localidades donde ya se han registrado estas especies con el fin de contar con la información para una re-evaluación de su estado de conservación. Mis registros, juntos con seis localidades donde otros han registrado estas especies en los últimos años, añaden 15 localidades a las 12 que enumeraron Collar et al. (1992). Basándome en esta información nueva, recomiendo otorgarle la clasificación de "En Peligro" al Cuevero de Nava, H. navai, siguiendo el criterio $B$ de Mace y Lande (extensión del área de distribución $<5000 \mathrm{~km}^{2}$ ) y en lo extremadamente fragmentado de su hábitat. Recomiendo mantener la clasificación de "Vulnerable" para el Cuevero de Sumichrast, H. sumichrasti, dada su área de distribución un poco más extensa y menos fragmentada y a sus densidades poblacionales aparentemente más elevadas.

\section{Introduction}

Hylorchilus (Troglodytidae) is one of only nine genera of birds endemic to Mexico. It was formerly thought to contain only one species, which was considered "Vulnerable/Rare" by Collar et al. (1992) largely owing to its small range and few records. Recent fieldwork has led to two allopatric species now being recognized by many authorities (Atkinson et al. 1993, Collar et al. 1994, Howell and Webb 1995). One of these species (H. navai) was at first demoted to 
"Rare" status because a population was found in a protected area, the other $(H$. sumichrasti) retained the status of "Vulnerable/Rare" (Atkinson et al. 1993). Both were considered "Vulnerable" by Collar et al. (1994) based on new criteria for assigning threat categories but on little new information.

The ranges of each of these species as mapped in Howell and Webb (1995) are among the smallest ranges of any mainland Mexican bird species, being similar in extent to those of Rosita's Bunting Passerina rositae and Sumichrast's Sparrow Aimophila sumichrasti. These wrens are restricted to tropical evergreen and semi-evergreen forest growing over karstic terrain with large boulders (Collar et al. 1992, Howell and Webb 1995) and are known from few localities.

Suitable habitat is more widespread than the few records suggest, however, and the wrens are easy to overlook. For example, Crossin and Ely (1973) stated that, "without knowledge of the call note, a field worker would very likely never suspect the birds' presence. This probably accounts for the late discovery in the Chiapas locality [even though it was a place] where several competent field workers [had] collected in recent years". Even in the right habitat, these wrens can easily be missed without a thorough knowledge of their songs and calls since they are much more difficult to see than to hear, perhaps even more so than most other tropical forest birds.

It is important to stress the need for a thorough knowledge of the vocalizations of these species before attempting a census. The vocalizations of Sumichrast's Wren were poorly known until recently. Only the call and the "fast song", which somewhat resembles the song of Canyon Wren Catherpes mexicanus and which is given only at certain localities, have been published (Hardy and Delaney 1987, Hardy and Coffey 1991, Delaney 1992). The "slow song" and the "female song" were undescribed except for a written description of the former ("shorter series, usually of 3-5 notes ...") in Howell and Webb (1995). This "slow song" can easily be confused with that of the often sympatric Black-faced Grosbeak Caryothraustes poliogaster. The call of Sumichrast's Wren is variable but one common variant can easily be confused with the call of the sympatric Golden-fronted Woodpecker Centurus aurifrons. The song of Nava's Wren was completely unknown until this decade and was first described in Atkinson et al. (1993). Its song can sometimes be confused with those of Red-crowned Ant-Tanager Habia rubica, Blueblack Gosbeak Cyanocompsa cyanoides and even with some variants of White-breasted Wood-Wren Henicorhina leucosticta, and its call can sometimes be confused with that of Magnolia Warbler Dendroica magnolia. Therefore, auditory censuses of these species, although the best means of detecting their presence in an area, should be attempted only after extensive study of their vocalizations.

These wrens are common (found in relatively large densities) but local. Armed with a thorough knowledge of their vocalizations, their presence can usually be detected within 45 minutes of arriving in a suitable area, often considerably less (pers. obs.). On 1 and 2 January 1992, 8 May 1995, and from 2 to 30 April 1996, I explored areas of potentially suitable habitat, as well as a few localities where Hylorchilus wrens were already known to occur, in order to gather new data for a re-evaluation of the conservation status of these species. 
Table 1. New localities for Nava's Wren (Hylorchilus navai)

\begin{tabular}{lll}
\hline & Locality & Source \\
\hline $1-1$ & c. Turnoff to Río Amaca, Oaxaca $\left(17^{\circ} 08^{\prime} \mathrm{N}, 94^{\circ} 50^{\prime} \mathrm{W}\right)$ & 8 May 1995 \\
$1-2$ & Río Chalchijapan, Veracruz $\left(17^{\circ} 13^{\prime} \mathrm{N}, 94^{\circ} 45^{\prime} \mathrm{W}\right)$ & 1 January 1992 \\
$1-3$ & Río Alegre, Veracruz $\left(17^{\circ} 12^{\prime} \mathrm{N}, 94^{\circ} 41^{\prime} \mathrm{W}\right)$ & 12 April 1996 \\
$1-4$ & Unnamed, Veracruz $\left(17^{\circ} 14^{\prime} \mathrm{N}, 94^{\circ} 38^{\prime} \mathrm{W}\right)$ & A. Zimmerman in litt. (per S. \\
& Poblado Nueve, Veracruz $\left(17^{\circ} 20^{\prime} \mathrm{N}, 94^{\circ} 27^{\prime} \mathrm{W}\right)$ & Howell) \\
$1-5$ & Unnamed, Veracruz $\left(17^{\circ} 18^{\prime} \mathrm{N}, 94^{\circ} 23^{\prime} \mathrm{W}\right)$ & 13 April 1996 \\
$1-6$ & Near type locality, Chiapas. $\left(16^{\circ} 56^{\prime} \mathrm{N}, 93^{\circ} 48^{\prime} \mathrm{W}\right)$ & Howell) \\
\end{tabular}

Collar et al.'s (1992) "locality 8 " refers to the combined localities 1-6.

\section{Methods}

Potentially suitable habitat was identified using the maps of Espinasa-Pereña (1992) for tropical karst and Rzedowski and Reyna-Trujillo (1992) for tropical evergreen and semi-evergreen forest. One morning, or only a few hours, were spent at most localities. Owing to time constraints and difficult terrain, it was possible to census each species at only two or three localities.

No attempt was made to estimate actual densities from transect data. Only the numbers of birds seen or heard are reported. However, I was able to obtain a more reliable estimate of actual density in one locality. During the censuses, birds were not stimulated to sing by playing recordings of their species's vocalizations. Distances were measured by pacing or using the car odometer.

\section{Results and discussion}

\section{Status of Nava's Wren Hylorchilus navai}

Nava's Wren was searched for in 15 localities containing tropical karst rainforest (Gómez de Silva 1996). It was not found in any of the localities to the north or east of its previously known range but was found slightly further west than all previous records, leading to the first sighting of the species in the State of Oaxaca. Additionally, the species was found at a site at or very close to its type locality (R.A. Andrle in litt. to P.W. Atkinson, pers. obs.), in an area where reportedly it had failed to be found (Atkinson et al. 1993). My records, together with two localities where the species was found by A. Zimmerman, R. A. Rowlett, K. Collins, T. Wendt and others (A. Zimmerman in litt. to S. Howell), add six localities to the three listed by Collar et al. (1992) (Table 1, Figure 1). All localities are from tropical evergreen forest.

The species is known from one protected area, the Reserva Especial de la Biósfera Selva El Ocote. The southern third of this $48,140-h a$ reserve is at higher elevations than known localities for Nava's Wren (>80o m a.s.1.) and therefore is probably unsuitable. This species had previously been found in the north-western edge of the reserve (Atkinson et al. 1993). I searched for it in one locality of suitable-looking habitat in the north-east of the reserve (above Rancho 


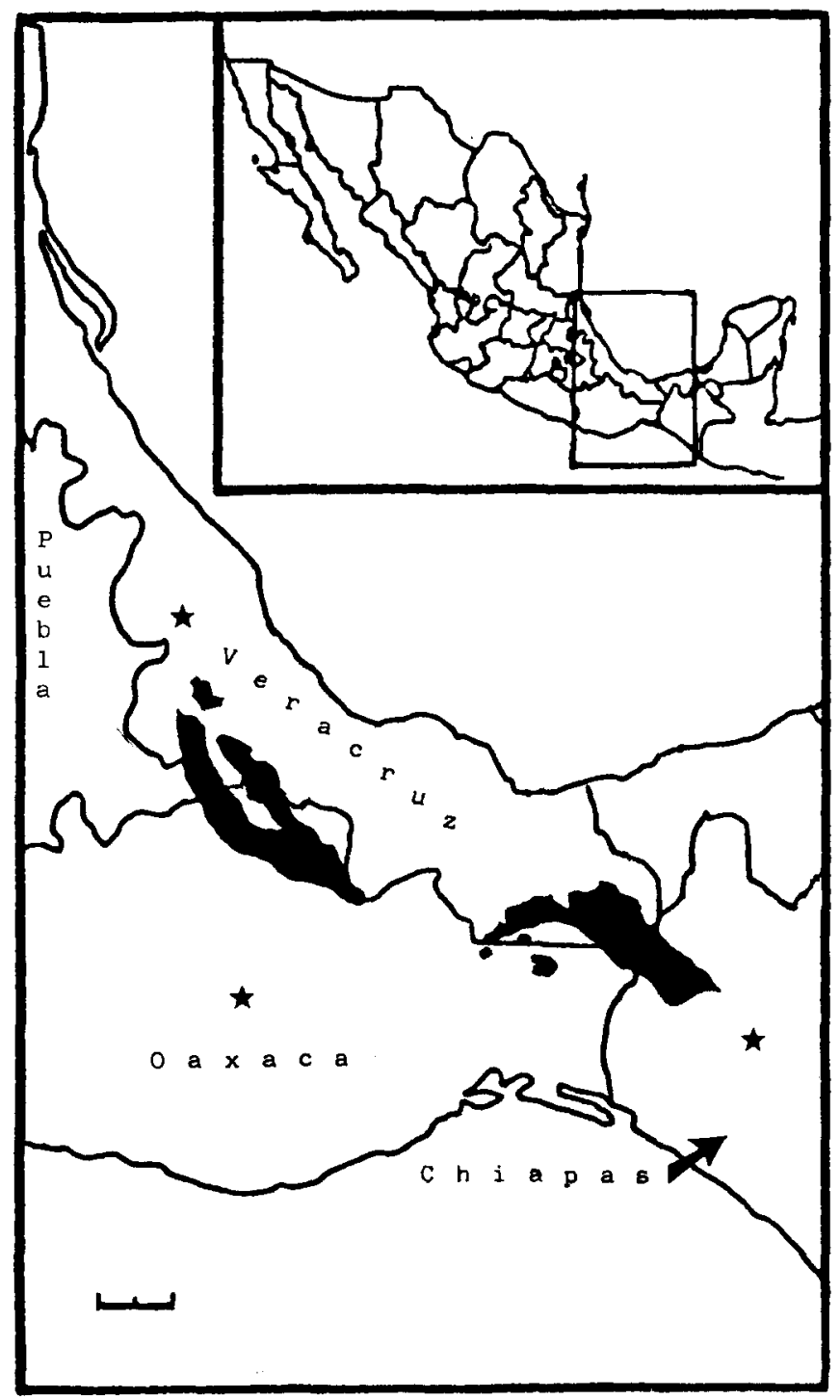

Figure 1. Ranges of Hylorchilus wrens. The dark areas on the left of the map show the range of Sumichrast's Wren whereas those on the right show the range of Nava's Wren. Names are given for the Mexican states where these wrens are found (stars represent state capitals). The scale bar equals $52 \mathrm{~km}$.

El Recuerdo), only about $20 \mathrm{~km}$ due east of the previous record, but failed to find it despite a relatively long search (six hours within suitable habitat).

I was able to census Nava's Wren at two sites (localities 1-5 and 1-7). These resulted in slightly lower numbers than Sumichrast's Wren. At both sites, four individuals were heard in a $300 \mathrm{~m}$ transect. Assuming that the detectabilities of both species are roughly equal (and I believe that this is so), then Nava's Wren appears to have a slightly lower population density than Sumichrast's Wren, as 
reported by Atkinson et al. (1993). This refers to numbers of individuals within suitable habitat. Suitable habitat for Nava's Wren, however, is far more patchily distributed than that of Sumichrast's Wren. For example, although the Uxpanapa region of southernmost Veracruz is mapped by Espinasa-Pereña (1992) as a continuous strip of tropical karst measuring more than $100 \mathrm{~km}$ from east to west, it was found that most of the region was flat, without rock outcrops, and had been largely converted into pastures, interspersed with small orange, coffee and rubber plantations. Karst outcrops and Nava's Wrens are mostly restricted to small, still-forested, isolated hillocks dotting these pastures. Most of these hillocks measure only around $200 \times 400 \mathrm{~m}$, with many of the largest ones measuring roughly $800 \times 800 \mathrm{~m}$ in area. There is roughly one hillock every $4 \mathrm{~km}^{2}$ and they are used to provide firewood. Two hillocks I searched did not contain Nava's Wren and both had been heavily logged. On the other hand, even small forest patches, when not heavily disturbed, contain Nava's Wren. For example, one Nava's Wren was found at one of the smaller $(200 \times 400 \mathrm{~m}$ or less) patches of karst forest at locality 1-1 (Table 1). Unfortunately, I could not spend more than a few minutes at this patch of forest, but I suppose that a patch of this size can support at least one pair of mature individuals.

A planned highway to connect Tuxtla Gutiérrez, the capital of Chiapas, with central Mexico would have bisected the range of Nava's Wren and indirectly increased human impact on this species, but it was re-routed in 1992, only two years after the rediscovery of Nava's Wren, and now only touches its range tangentially at one point, close to its type locality.

Based on the map of tropical karst in Espinasa-Pereña (1992), I estimate the "extent of occurrence" of Nava's Wren at between 4800 and $4900 \mathrm{~km}^{2}$. The area actually occupied must be extremely small, however, and is becoming more fragmented as the remnant patches continue to be used for wood. I recommend "Endangered" status for Nava's Wren based on criterion B of Mace-Lande (extent of occurence $<5000 \mathrm{~km}^{2}$ ) and on the fragmentation (both natural and artificial) of its habitat.

\section{Status of Sumichrast's Wren Hylorchilus sumichrasti}

Sumichrast's Wren (Figure 2) was searched for in nine localities (Gómez de Silva 1996). This resulted in the first record for this species in the State of Puebla, and the easternmost record for the species, on the road to San Juan del Río, Oaxaca. I looked for this species still further east, to see if it was possible to bridge the distribution gap between the two Hylorchilus wrens, but it was not found and neither is there suitable habitat (karst). Thus, there is a real gap of around $106 \mathrm{~km}$ between the two. The species was found about $1 \mathrm{~km}$ from Temascal, Oaxaca, where Atkinson et al. (1993) had failed to find it after a brief search. My records, together with four localities where the species was found by Wauer (1992), DeSucre-Medrano et al. (in press) and A. Navarro and G. Escalona (pers. comm.), add nine localities to those listed by Collar et al. (1992) (Table 2 and Figure 1).

These localities range from tropical semi-evergreen to evergreen forest (Figure 3). During the wet season (roughly from June to October) these two types of forests are very similar to each other but obvious differences become apparent at the end of the dry season, from March to May. Up to $50 \%$ of the trees in the 


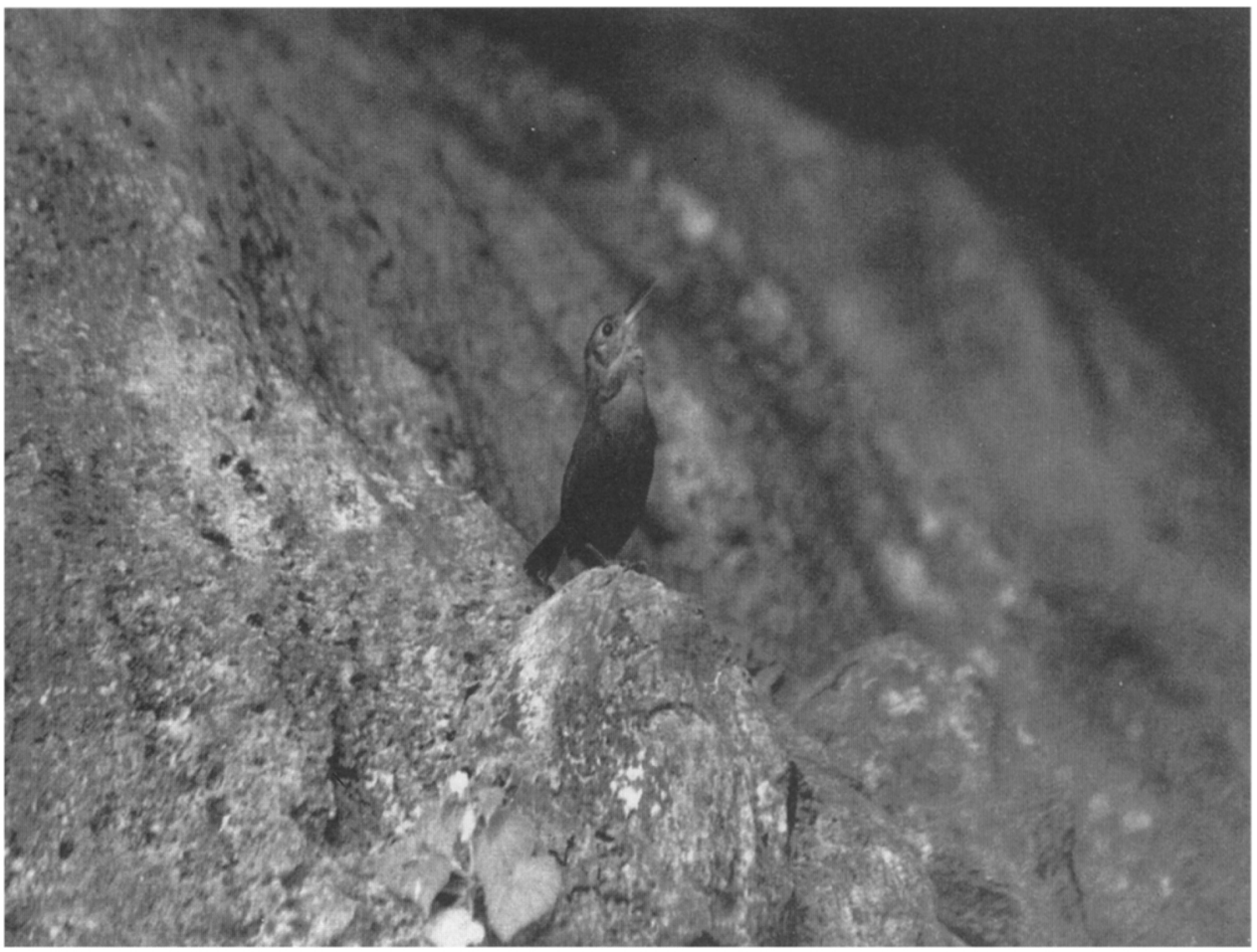

Figure 2. Male Sumichrast's Wren singing at the mouth of a limestone cave in Cerro de Oro (locality 2-6). (Photographed by Mónica Pérez Villafaña, August 1994.)

Table 2. New localities for Sumichrast's Wren (Hylorchilus sumichrasti)

\begin{tabular}{|c|c|c|}
\hline & Locality & Source \\
\hline 2-1 & Xúchiles, Veracruz $\left(18^{\circ} 45^{\prime} \mathrm{N}, 96^{\circ} 5^{\circ} \mathrm{W}\right)$ & Wauer (1992) \\
\hline $2+2$ & Other side of river from La Pedrera, Puebla $\left(18^{\circ} 3 x^{\prime} \mathrm{N}, 96^{\circ} 4^{\prime} \mathrm{W}\right)$ & 29 April 1996 \\
\hline $2-3$ & San Martín Caballero, Oaxaca (approx. $1^{\circ} \circ 7^{\prime} \mathrm{N}, 96^{\circ} 38^{\prime} \mathrm{W}$ ) & G. Escalona (pers. comm.) \\
\hline $2-4$ & c. Agua Escondida, Oaxaca $\left(18^{\circ} 32^{\prime} \mathrm{N}, 96^{\circ} 37^{\prime} \mathrm{W}\right)$ & 22 April 1996 \\
\hline $2-5$ & $1 \mathrm{~km} S$ of Temascal, Oaxaca $\left(18^{\circ} 14^{\prime} \mathrm{N}, 96^{\circ} 24^{\prime} \mathrm{W}\right)$ & 23 April 1996 \\
\hline $2-6$ & Cerro de Oro, Oaxaca $\left(18^{\circ} 01^{\prime} \mathrm{N}, 96^{\circ} 15^{\prime} \mathrm{W}\right)$ & DeSucre et al. (in press) \\
\hline $2-7$ & $2 \mathrm{~km} \mathrm{~S}$ of Bethania, Oaxaca $\left(17^{\circ} 56^{\prime} \mathrm{N}, 96^{\circ} 01^{\prime} \mathrm{W}\right)$ & 25-26 April 1996 \\
\hline $2-8$ & Cerro Chango, Río Manso, Oaxaca $\left(17^{\circ} 42^{\prime} \mathrm{N}, 95^{\circ} 55^{\prime} \mathrm{W}\right)$ & DeSucre et al. (in press) \\
\hline $2-9$ & Oax./Ver. border, road to San Juan del Río $\left(17^{\circ} 32^{\prime} \mathrm{N}, 95^{\circ} 44^{\prime} \mathrm{W}\right)$ & 24 April 1996 \\
\hline $2-10$ & Rancho/Raya Caracol, Oaxaca $\left(18^{\circ} 18^{\prime} \mathrm{N}, 96^{\circ} 43^{\prime} \mathrm{W}\right)$ & traced using 1982 map \\
\hline
\end{tabular}

I have traced Collar et al.'s (1992) locality 7 ("Rancho Caracol, $48 \mathrm{~km}$ south of Tezonapa") to "Raya Caracol"' (my locality 10).

semi-evergreen forest lose their leaves at the peak of the dry season (Miranda and Hernández-X 1963) whereas almost none lose their leaves in the evergreen forest. Therefore, much light reaches the floor of the semi-evergreen forest in the drier part of the year. The most extreme instances of leaf-fall were found at locality 2-5 and in parts of the forest at locality 2-7. Sumichrast's Wren is now 
known from coffee plantations with shade trees at two sites: Amatlán, Veracruz (where formerly recorded; e.g. Hardy and Delaney 1987, Atkinson et al. 1993), and locality 4 (Table 2 ). These plantations exist in semi-evergreen forest; though dry-season leaf-fall is not as extreme as in localities 2-5 and 2-7, some of the original trees have been felled and the canopy is broken, with much light reaching the ground. These observations add a caveat to the often-repeated statements on the strong need for shade and closed-canopy forests by Hylorchilus wrens (Collar et al. 1992, Atkinson et al. 1993).

Two localities for this species were not traced with precision by Collar et al. (1992). One of these is the type locality, Mata Bejuco, stated by Nelson (1897) to be in the same region as Motzorongo. Phillips (1991: 223) thought that Mata Bejuco may have been the local name of the bird, not a locality but, although I have been unable to trace it, I believe that this really is the name of a locality. Another untraced record comes from "Rancho Caracol", the locality of two 1948 specimens (Collar et al. 1992), said to be " $48 \mathrm{~km}$ south of Tezonapa". It is likely that this locality refers to what is now called "Raya Caracol", $25 \mathrm{~km}$ south of Tezonapa as the crow flies, but reached by heading generally southward along a winding road or river.

I censused Sumichrast's Wren at two sites. These censuses yielded counts of four individuals (locality 2-7) and seven individuals (locality 2-6) per $300 \mathrm{~m}$ transect, numbers larger than and equal to those of Nava's Wren. In April 1996 (dry season), I often heard two males singing at the same time whereas I have never heard this in Nava's Wren. In the rainy season, when Hylorchilus wrens sing even more frequently, I have heard up to five males sing nearly at the same time (17 July 1994, locality 2-6), whereas Atkinson et al. (1993) said of Nava's Wren, also in the rainy season, that "only infrequently were two individuals heard at the same time". Sumichrast's Wren may therefore be found at higher population densities than Nava's Wren.

A better idea of the population density of Sumichrast's Wren comes from observations at a very small patch of karst forest in the eastern end of its range (locality 2-9). I spent one whole morning reconnoitring this patch which measured only $75 \times 40 \mathrm{~m}$, separated from the next patch by about $300 \mathrm{~m}$ of treeless pasture. Two male and two female Sumichrast's Wrens were countersinging, two pairs apparently having their territories in less than 0.5 ha of suitable habitat. It is unlikely that they represented one mature pair with immatures since the breeding season was barely beginning, records of nests of this species being all from May (Bangs and Peters 1927, Collar et al. 1992, M. Pérez Villafaña, pers. comm.). Also I do not think that this census is inflated by attributing the area of this one patch of karst forest to individuals that actually inhabited more than the one patch, as I heard at least one of the pairs all morning and heard both pairs simultaneously from ogh3o to 10 hoo and from 12 hoo to 13hoo. It seems unlikely that small tropical birds with rounded wings would regularly commute between forest patches $300 \mathrm{~m}$ or more apart.

In contrast to the situation with Nava's Wren, the range of Sumichrast's Wren is above the threshhold for Mace-Lande "Endangered" status (more than $6000 \mathrm{~km}^{2}$ in extent). Also, much of it is unfragmented, being along the foothills of long and unbroken mountain ranges. Some areas of its habitat are being 
(a)

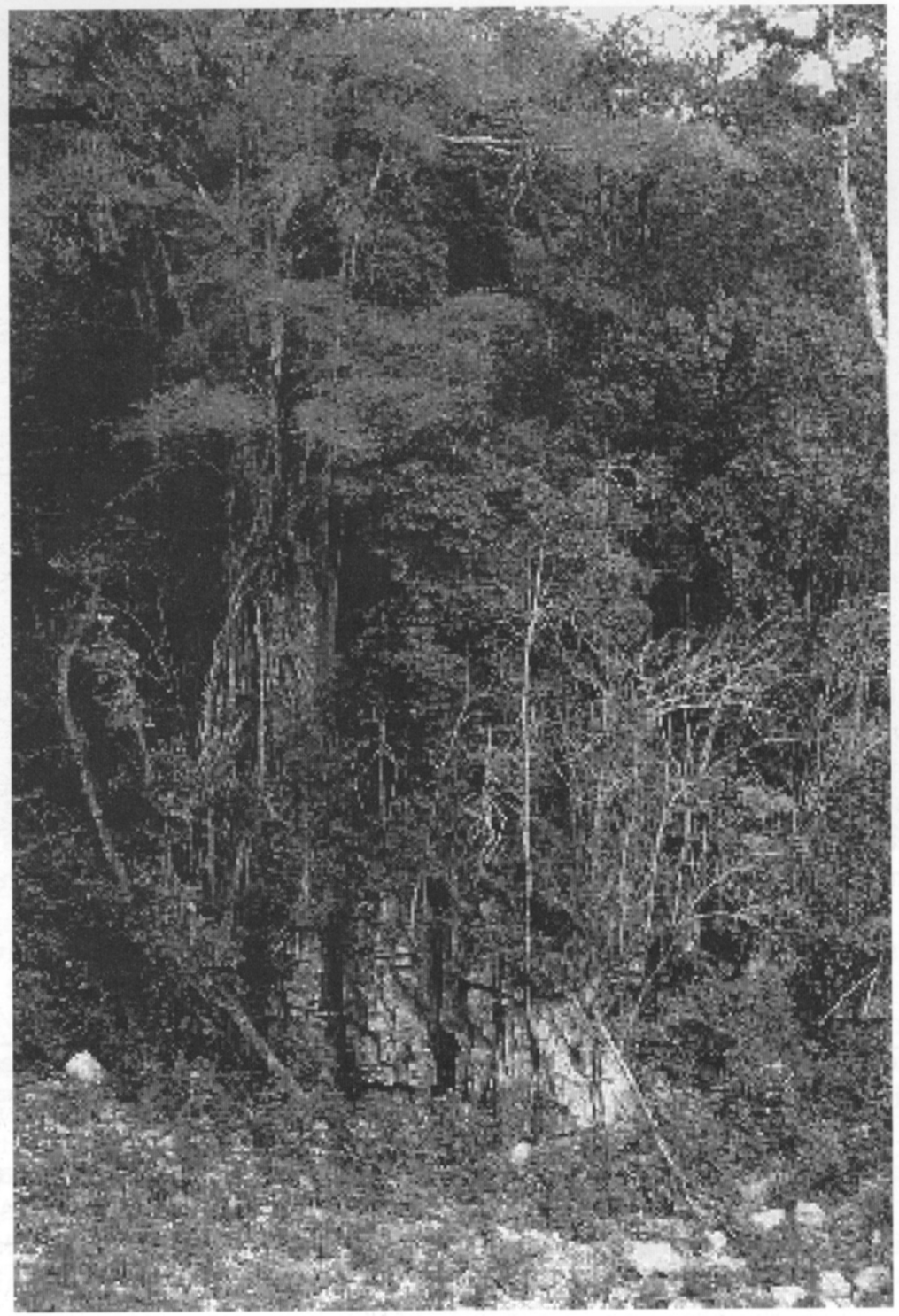

cleared, but this occurs much less frequently than for Nava's Wren. I would therefore retain "Vulnerable" status for Sumichrast's Wren. This species is not known from any officially protected area.

\section{Acknowledgements}

This work was supported by a grant from the International Council for Bird Preservation Pan American Continental Section (now called American Bird Conservancy) and the U.S. Fish and Wildlife's Office of International Affairs. I would like to thank Atahualpa DeSucre-Medrano, Griselda Escalona, Steve N.G. Howell, Adolfo Navarro and Mónica Pérez Villafaña for sharing unpublished information on the distribution of Sumichrast's 
(b)

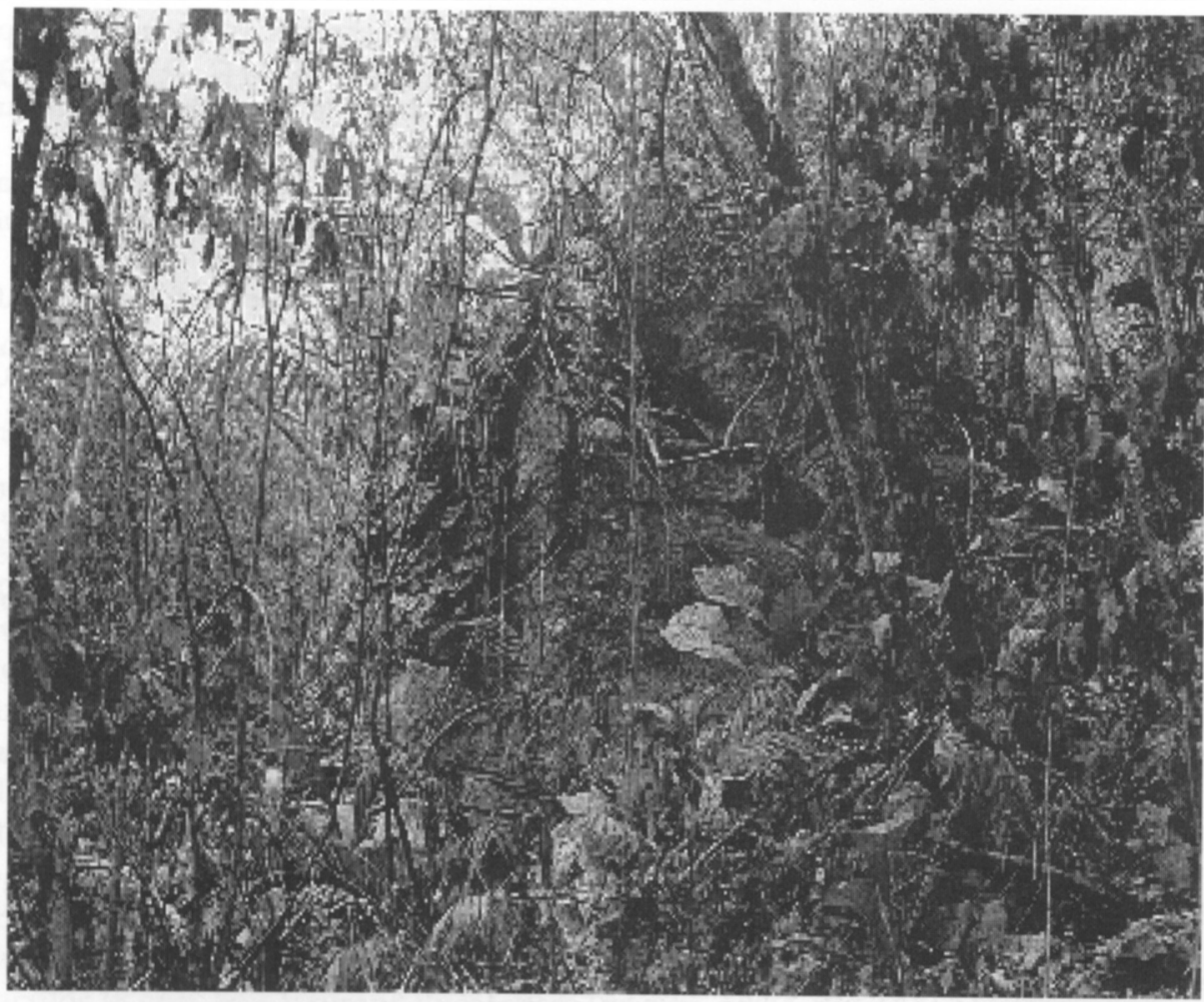

Figure 3. Dry season aspect of the two types of forest where Hylorchilus wrens are found. Both photographs were taken in April. a. Karst boulder in tropical evergreen forest close to the type locality of Nava's Wren (locality 1-7). Note the deep shade between the tree trunks. $b$. Karst boulder in tropical semi-evergreen forest about $\mathrm{I} \mathrm{km}$ south of Temascal (locality 2-5). Note that in this type of forest there are fewer trees with wide trunks and, in the dry season, the leaves that have not been shed are limp and more sunlight reaches the ground than in a tropical evergreen forest.

Wren with me, and to Enrique Martínez Meyer for his help making the map shown in Figure 1. I am especially indebted to my 1996 field assistant, Héctor Cervantes Maya, for his help in logistic aspects of the fieldwork. Without his cheerful and expert assistance, the fieldwork would not have been possible.

\section{References}

Atkinson, P., Whittingham, M., Gomez de Silva, H., Kent, A. and Maier, R. (1993) Notes on the ecology, conservation and taxonomic status of Hylorchilus wrens. Bird Conserv. Int. 3: 75-85.

Bangs, O. and Peters, J.L. (1927) Birds from the rain forest region of Veracruz. Bull. Mus. Comp. Zool. 67: 471-487.

Collar, N. J., Gonzaga, L. P., Krabbe, N., Madroño Nieto, A., Naranjo, L. G., Parker, T. A. and Wege, D. C. (1992) Threatened birds of the Americas. Cambridge, U.K: International Council for Bird Preservation.

Collar, N. J., Crosby, M. J. and Stattersfield, A. J. (1994) Birds to watch 2: the world list of threatened birds. Cambridge, U.K.: Birdlife International. Birdlife Conservation Series 4. 
Crossin, R. S. and Ely, C. A. (1973) A new race of Sumichrast's Wren from Chiapas, Mexico. Condor 75: 137-139.

Delaney, D. (1992) Bird songs of Belize, Guatemala, and Mexico. Library of Natural Sounds, Ithaca, New York: Cornell University.

DeSucre-Medrano, A., Paredes-Zárate, R., Pérez-Villafaña, M. G., Ramirez-Bastida, P. and Varona-Granel, D. E. (in press) Recent record of Sumichrast's Wren (Hylorchilus sumichrasti) in the state of Oaxaca, Mexico. Euphonia.

Espinasa-Pereña, R. (1992) Carso (Karst), Escala 1: 8,00o,ooo, in "Geomorfología 2", Atlas Nacional de México. México, D.F.: Instituto de Geografía, UNAM.

Gómez de Silva, H. (1996) Report on the distribution and conservation status of Hylorchilus wrens. Washington, D.C.: U.S. Fish and Wildlife Service, Office of International Affairs and American Bird Conservancy.

Hardy, J. W. and Coffey, B. B. (1991) Voices of the wrens. Gainesville, Florida: ARA Records.

Hardy, J. W. and Delaney D. (1987) The vocalizations of the Slender-billed Wren (Hylorchilus sumichrasti): who are its close relatives? Auk 104: 528-530.

Howell, S. N. G. and Webb, S. (1995) A guide to the birds of Mexico and northern Central America. Oxford, U.K: Oxford University Press.

Miranda, F. and Hernández-X, E. (1963) `Los tipos de vegetación de México y su clasificación. Bol. Soc. Bot. México 28: 133-176.

Nelson, E. W. (1897) Preliminary descriptions of new birds from Mexico and Guatemala in the collections of the United States Department of Agriculture. Auk 14: 42-76.

Phillips, A. R. (1991) The known birds of North and Middle America. II. Denver, Colorado: published by authors.

Rzedowski, J. and Reyna-Trujillo, T. (1992) "Vegetación Potencial", Map IV.8.2 in Atlas Nacional de México. México, D.F.: Instituto de Geografía, UNAM.

Wauer, R. H. (1992) A naturalist's Mexico. College Station, Texas: Texas A\&M Press.

HECTOR GOMEZ DE SILVA

Instituto de Ecología, UNAM; Apartado Postal 70-275; Ciudad Universitaria; C.P. 04510 México, D.F.; Mexico. 